\title{
Paediatric Friendly Dosage Form for Enhanced Therapeutic Efficacy in Aids and the Opportunistic Infection Tuberculosis
}

\author{
Mathur M, Raichur V and V Kusumdevi* \\ Department of Pharmaceutics, Al-Ameen College of Pharmacy, Bangalore, Karnataka, India
}

Received Date: March 21, 2018; Published Date: April 09, 2018

*Corresponding author: Dr. V Kusum Devi, Professor and Head of Department, Pharmaceutics Division, Al-Ameen College of Pharmacy, Nr. Lalbaug Main Gate, Hosur Road, Bangalore, Karnataka, India, Tel: 080-22234619; Email: aacp112015@gmail.com

\begin{abstract}
AIDS is one of the most widely prevalent diseases affecting the paediatric population and the treatment becomes difficult due to the age related barriers. Further, anti-retroviral therapy has been less effective due to lack of efficacy and other drug related issues. A patient friendly dosage form is the need of the hour as a part of the effective ART plan of WHO. Nanoparticles loaded buccal patches were prepared to cater the requirements of the paediatric population. Buccal patches were prepared using mucoadhesive polymer, viz. hydroxpropyl methyl cellulose (HPMC) E15 Lv in a concentration of 15\% w/w along with polyethylene glycol (PEG) 400 and Propylene glycol (PG) as plasticizer. The prepared buccal patches were evaluated for various technological parameters like thickness, folding endurance, moisture uptake, in-vitro disintegration time etc. Further, in-vitro and ex-vivo drug release studies were also conducted to understand the pattern of drug release and the time required to attain the maximum drug release. Cellular uptake studies showed a greater internalisation of NP's in the A 431 cells hence supporting the greater permeation of nanoparticles from the patches, proving to be a excellent platform technology with superior qualities like enhanced patient compliance and effective drug therapy.
\end{abstract}

Keywords: Anti-Retrovirals; Buccal Patches; Cellular Uptake; Ex-Vivo Permeation

Abbreviations: AIDS: Acquired Immuno Deficiency Syndrome; ART: Anti-Retro Viral; HIV: Human Immunodeficiency Virus; WHO: World Health Organization; NNRTI: Non-Nucleoside Reverse Transcriptase Inhibitor; sd-NVP: single dose Nevirapine; FDCs: Fixed-Dose Combinations; IPT: Isoniazid Preventive Therapy; NEV: Nevirapine; STA: Stavudine; LAM: Lamivudine; ISO: Isoniazid; HPMC: Hydroxyl Propyl Methyl Cellulose; PEG: Polyethylene Glycol; PG: Propylene Glycol

\section{Introduction}

Acquired immuno deficiency syndrome (AIDS) is spectra of conditions caused by the human immunodeficiency virus (HIV) [1]. An estimated 36.7 million people were living with HIV worldwide in 2016. Of these, 2.1 million were children under 15 years of age and about 18.8 million were women and girls. Each day approximately 5,000 people were newly infected with HIV and approximately 2,800 people died from AIDS, mostly because of inadequate access to HIV prevention care and treatment services in the year 2016 [2]. Conventional dosage forms recommended by US FDA and WHO for the treatment of AIDS involves a combination of antiretroviral drugs given in the form of tablets, capsules, oral solutions and suspension preparations. Currently, World Health Organization (WHO) has implemented the anti-retro viral (ART) therapy which includes drugs like lamivudine, stavudine and Neverapine in combination for effective therapy. However, at present, the WHO recommended antiretro-viral therapy (Nevirapine+ Stavudine+ Lamivudine) for paediatrics is not available in the market in a compact or patient compliant form which can be easily ingested by the child for effective control of AIDS symptoms. Presently available tablet formulation has to be broken into parts and given twice daily. Such a practice results in inconvenience to the child as well as to the person administering the medicine in addition to dose imprecision which is likely to occur leading to sub therapeutic activity of drugs or incidence of associated side effects with antiretroviral therapy which can also result in failure of therapy $[3,4]$.

The use of single dose Nevirapine (sd-NVP) at the onset of labour significantly reduces peri-partum HIV transmission $[5,6]$. However, this approach is less effective than other ARV prophylactic regimen and may be associated with acquisition 
of viral resistance to non-nucleoside reverse transcriptase inhibitor (NNRTI) drugs. Additionally, the use of sd-NVP does not reduce HIV transmission risk during the breastfeeding period [6]. Important considerations for ART regimens for infants and children include: the availability of a suitable formulation that can be taken in appropriate doses; simplicity of the dosage schedule; the taste and palatability, and thus the potential for compliance in young children [7]. Fixed-dose combinations (FDCs) are increasingly available for younger children, and are preferred to syrups and single drugs because they promote and support treatment adherence and reduce the cost of treatment.
Adult tablets that require cutting up can result in under dosing or overdosing when given to children, and this may lead to an increased risk of resistance or toxicity [8]. Availability of paediatric formulations may ensure that the use of adult dose solid formulations is not resorted to. Dosing of antiretroviral drugs in children is usually based on either body surface area, or weight, or more conveniently by weight band (as in the National programme). As these change with the growth, drug doses must be adjusted for weight in order to avoid under-dosing. Hence in this regard a suitable dosage form for these drugs in combination is the need of the hour $[7,8]$ (Figure 1).

\begin{tabular}{|c|c|c|c|c|c|c|c|c|c|c|c|c|c|c|}
\hline \multicolumn{14}{|c|}{$\begin{array}{l}\text { Table 4: Simplified harmonized dosing schedule for ideal antiretroviral products used in first line regimens } \\
\text { First line options }\end{array}$} & $\begin{array}{l}\text { Share t } \\
\text { and se }\end{array}$ \\
\hline \multirow{3}{*}{ Drug } & \multirow{3}{*}{$\begin{array}{l}\text { Strength } \\
\text { of child } \\
\text { tab (mg) }\end{array}$} & \multicolumn{9}{|c|}{ Number of tablets by weight band (twice daily) } & \multirow{3}{*}{$\begin{array}{l}\text { Strength of } \\
\text { adult tab } \\
\text { (mg) }\end{array}$} & \multirow{2}{*}{\multicolumn{2}{|c|}{$\begin{array}{l}\text { Number of } \\
\text { tablets by } \\
\text { weight band } \\
\text { (twice daily) }\end{array}$}} & \\
\hline & & \multicolumn{2}{|c|}{$\begin{array}{c}\text { Children less } \\
\text { than } 6 \\
\text { months of } \\
\text { age }\end{array}$} & \multicolumn{7}{|c|}{ Children 6 months of age and above } & & & & \\
\hline & & $\begin{array}{c}3.3 .9 \\
\mathrm{~kg}\end{array}$ & $\begin{array}{c}4.4 .9 \\
\mathrm{~kg}\end{array}$ & $\begin{array}{c}3-3.9 \\
\mathrm{~kg}\end{array}$ & $\begin{array}{c}4-4.9 \\
\mathrm{~kg}\end{array}$ & $\begin{array}{c}5-5.9 \\
\mathrm{~kg}\end{array}$ & $\begin{array}{c}6-9.9 \\
\mathrm{~kg}\end{array}$ & $\begin{array}{c}10 . \\
13.9 \\
\mathrm{~kg}\end{array}$ & $\begin{array}{c}14 \\
19.9 \\
\mathrm{~kg}\end{array}$ & $\begin{array}{c}20- \\
24.9 \\
\mathrm{~kg}\end{array}$ & & $\begin{array}{c}25- \\
29.9 \\
\mathrm{~kg}\end{array}$ & $\begin{array}{c}30- \\
34.9 \\
\mathrm{~kg}\end{array}$ & \\
\hline $\mathrm{AZT}$ & 60 & 0.5 & 0.75 & 1 & 1 & 1 & 1.5 & 2 & 2.5 & 3 & 300 & 1 & 1 & \\
\hline $\mathrm{AZT} / 3 \mathrm{TC}$ & $60 / 30$ & 0.5 & 0.75 & 1 & 1 & 1 & 1.5 & 2 & 2.5 & 3 & $300 / 150$ & 1 & 1 & \\
\hline AZT/3TC/NVP & $60 / 30 / 50$ & 0.5 & 0.75 & 1 & 1 & 1 & 1.5 & 2 & 2.5 & 3 & $300 / 150 / 200$ & 1 & 1 & \\
\hline $\mathrm{ABC} / 3 \mathrm{TC} / \mathrm{NVP}$ & $60 / 30 / 50$ & 0.5 & 0.75 & 1 & 1 & 1 & 1.5 & 2 & 2.5 & 3 & $300 / 150 / 200$ & 1 & 1 & \\
\hline $\mathrm{ABC}$ & 60 & 0.5 & 0.75 & 1 & 1 & 1 & 1.5 & 2 & 2.5 & 3 & 300 & 1 & 1 & \\
\hline $\mathrm{ABC} / 3 \mathrm{TC}$ & $60 / 30$ & 0.5 & 0.75 & 1 & 1 & 1 & 1.5 & 2 & 2.5 & 3 & $300 / 150$ & 1 & 1 & \\
\hline $\mathrm{ABC} / \mathrm{AZT} / 3 \mathrm{TC}$ & $60 / 60 / 30$ & 0.5 & 0.75 & 1 & 1 & 1 & 1.5 & 2 & 2.5 & 3 & $300 / 300 / 150$ & 1 & 1 & \\
\hline $3 \mathrm{TC}$ & \begin{tabular}{|l|}
30 \\
\end{tabular} & 0.5 & 0.75 & 1 & 1 & 1 & 1.5 & 2 & 2.5 & 3 & 150 & 1 & 1 & \\
\hline $\mathrm{d} 4 \mathrm{~T}$ & 6 & 0.5 & 0.75 & 1 & 1 & 1 & 1.5 & 2 & 2.5 & 3 & \begin{tabular}{|l|}
30 \\
\end{tabular} & 1 & 1 & \\
\hline $\mathrm{d} 4 \mathrm{~T} / 3 \mathrm{TC}$ & $6 / 30$ & 0.5 & 0.75 & 1 & 1 & 1 & 1.5 & 2 & 2.5 & 3 & $30 / 150$ & 1 & 1 & \\
\hline $\mathrm{d} 4 \mathrm{~T} / 3 \mathrm{TC} / \mathrm{NVP}$ & $6 / 30 / 50$ & 0.5 & 0.75 & 1 & 1 & 1 & 1.5 & 2 & 2.5 & 3 & $30 / 150 / 200$ & 1 & 1 & \\
\hline NVP & 50 & 0.5 & 0.75 & 1 & 1 & 1 & 1.5 & 2 & 2.5 & 3 & 200 & 1 & 1 & \\
\hline
\end{tabular}

Figure 1: Simplified harmonized dosing schedule for ideal antiretroviral products used in first line regimens.

Moreover, a conventional tablet containing combination of antiretroviral drugs, $07 \mathrm{mg}$ stavudine; $50 \mathrm{mg}$ lamivudine with $55 \mathrm{mg}$ nevirapine is recommended for child weighing 10 to < $30 \mathrm{~kg}$. Such doses of the recommended fixed dose combinations are not available in the market; instead $12 \mathrm{mg}$ stavudine; 60 mg lamivudine with $100 \mathrm{mg}$ nevirapine is available in a market named Triomune Junior $\AA$. This implies that currently available generic fixed dose combination (FDC) does not follow the recommended dosing. Similarly, the other FDC's available for child weighing $>6 \mathrm{~kg}$ and $<30 \mathrm{~kg}$ are given as 1.5 tablet twice daily. In conjunction to the associated drawbacks with conventional therapy in paediatric patient, incompliance due to swallowing a tablet is also another problem which can be overcome by formulating NDDS in a patient friendly dosage form [9].

Many ARV drugs undergo extensive first pass metabolism and gastrointestinal degradation leading to low and erratic bioavailability, for example Stavudine, the half-life is $<1 \mathrm{hrs}$ in paediatrics and oral bioavailability is $76 \%$ in children with normal renal function [10]. Other drugs such as Lamivudine have an oral bioavailability of 87\%, half-life of 5-7 hr in children.
It also shows lesser bioavailability due to inaccessible entry to the sites in required therapeutic concentrations like lymphatic system and macrophages and the short residence time at the required site of action which contributes significant failure of eliminating HIV from these reservoirs and the development of multidrug-resistance against the ARVs. This can further be attributed to the subsequent large doses essential for achieving a therapeutic effect, due to the inadequate drug concentrations at the site of action. Nevirapine suffer from physicochemical problems such as poor solubility that may lead to formulation difficulties. The various adverse effects associated with above drugs on prolonged use are pancreatitis, dyslipidemia, diarrhoea and peripheral neuropathy [11].

In order to fulfil the need of a long-term treatment with antiHIV agents, where most of them suffer from the drawbacks of frequent administration, plasma concentration fluctuation, it is desirable to have controlled or sustained-release drug delivery systems to improve the overall therapeutic benefit and to achieve an ideal therapy. A non-invasive zero-order delivery such as the buccal route is desirable, as controlled delivery via conventional 
oral route retains most of the drawbacks of drug delivery. Buccal delivery can provide sustained delivery of anti-HIV agents for a predetermined period at a predetermined rate. It can enhance the antiviral activity and reduce the dosing frequency and severity of toxic side effects by optimizing the blood concentration profiles within the therapeutic range for longer duration. It also improves the bioavailability by circumventing hepatic first pass, acid instability, intestinal permeability factor; which are the most common problems faced with the conventional oral route.

Nanoparticles have been explored for improving the formulation and efficacy of drugs with physico-chemical problems such as poor solubility, permeability and stability. They are being increasingly investigated for targeted delivery to HIV infected cells and to achieve sustained drug release kinetics. In this study the principles of nanotechnology will be applied to the selected anti retroviral drugs to optimize their therapeutic effect [12]. When HIV is introduced into the body, this virus is too strong for the helper $\mathrm{T}$ cells and killer T cells. The HIV virus cannot be destroyed and lives in the body undetected for months or years. Gradually, over a period, as the T cells become progressively destroyed or inactivated, other viruses or parasites (called "opportunistic diseases") which would not have been able to get past a healthy body's defence, can multiply within the body. Commonly seen opportunistic diseases in persons with HIV infection include: tuberculosis, candida (yeast) infection etc. In India it is believed that more than 1, 00,000 children suffering from AIDS are also suffering from tuberculosis. Global burden of number of children suffering from AIDS and tuberculosis is 3.2 million in 2013 [13].

A delivery mechanism that introduces the anti TB drugs selectively into macrophages will greatly increase their therapeutic index by achieving higher concentration of the drugs locally where $M$. tuberculosis replicates. This bacterium resides and multiplies within host mononuclear phagocytes and because mononuclear phagocytes internalize particles more efficiently than other host cells, encapsulation of anti TB drugs within nanoparticles offers a specific targeting to infected cells. The pharmacokinetic parameters such as, Elimination half-life of Isoniazid is found to be 2.5-4 hrs. Formulating a carrier based system of Isoniazid will help in attaining a sustained release action of drug as well [14]. As per WHO recommendations for the prevention of tuberculosis in paediatrics who are living with HIV, should receive at least 6 months of Isoniazid Preventive Therapy (IPT) $(10 \mathrm{mg} / \mathrm{kg} /$ day up to a maximum of $300 \mathrm{mg}$ given once daily) as part of a comprehensive package of HIV care. Thus it is proposed to design a novel drug delivery system containing the said anti retovirals with isoniazid [15].

The oral route of administration is the most common and convenient for paediatric use, therefore fast dissolving buccal films containing antiretroviral drugs as well as anti-tubercular drug will be formulated. Currently no dosage form is available which contains both the category of drugs together, so far anti
TB drugs are concomitantly administered to paediatrics after administering ARV's which further leads to inconvenience therefore by developing films containing both category of drugs will reduce the frequency as well as number of drug administration's at a time with enhanced therapeutic efficacy and compliance. Further, the selected best novel formulation in the form of paediatric friendly dosage form has been developed based on the dose requirement of different paediatric age groups cater to the dosage requirements of the age i.e., for infants $(0-2$ years), babies (2-6 years) and juniors (6-12 years) in order to address the issue related to each division of paediatric population for better compliance and effective therapy. Hence in the present research an attempt has been made to formulate and evaluate nanoparticles containing drugs loaded buccal patches of the above mentioned drugs with an aim of improving their permeability and cellular uptake, which will facilitate a better efficacy for the therapy, while at the same time maintaining a very patient compliant and accurate dosage for the paediatric population.

\section{Materials and Methods}

\section{Materials}

Drugs namely Nevirapine, Stavudine, Lamivudine and Isoniazid were obtained as gift samples from Mylan Laboratories Limited, Medak, Andhra Pradesh. Eudragit S-100 was obtained from Evonik India Pvt. Ltd, Mumbai. Chitosan, 65-75\% deacetylated, was a product of Himedia Pvt. Ltd., India. Surfactants like Poloxamer 407 and didodecyl dimethyl ammonium bromide were obtained from Sigma-Aldrich Pvt. Ltd, India, while Polyvinyl Alcohol and span 60 were obtained from SD fine chem. Ltd, Mumbai. Solvents like methanol and Acetone were obtained from SD Fine-Chem Limited, Mumbai. Sodium tripolyphosphate was obtained from Sigma-Aldrich Pvt. Ltd, India. Hydroxy Propyl Methyl Cellulose E15 Lv was obtained from Evonik India Pvt. Ltd, Mumbai. Polyethylene glycol 400 was a product of SDFCL Pvt. Ltd., India. Propylene glycol was obtained from Finar Pvt. Ltd, India, while Dibutyl phthalate were obtained from SD fine chem. Ltd, Mumbai. Solvents like Isopropyl alcohol and Acetone were obtained from SD Fine-Chem Limited, Mumbai. Dialysis membrane 12-14 kDa molecular weight cut-off was procured from Himedia, Laboratories Pvt. Ltd., Mumbai.

\section{Methods}

\section{Procedure for the Preparation of Mucoadhesive Fast Dissolving Buccal Patch Loaded with Drug Loaded Nanoparticles}

Nanoparticles of Nevirapine were prepared by nano precipitation method using Eudragit S100 as the polymer. Nanoparticles of Lamivudine, stavudine and isoniazid were prepared by double emulsion method using Eudragit S100 as the polymer. Further, evaluation and characterization of these nanoparticles were carried out and were found to be satisfactory. Different mucoadhesive polymers and plasticizers 
and their concentrations were screened for the preparation of mucoadhesive film. Further, volumes of casting solution and mould size were also screened for the same. Appearance, stability and strength of the formed mucoadhesive films were taken into consideration for selection of these formulation and process variables [16]. A brief description of these screening studies is shown in (Table 1). Mucoadhesive fast dissolving buccal patches of the four different drug loaded nanoparticles namely Nevirapine (NEV), Stavudine (STA), Lamivudine (LAM) and Isoniazid (ISO) were formulated by solvent casting method. Hydroxyl Propyl Methyl Cellulose (HPMC) E 15Lv was used a polymer which was allowed to soak overnight in distilled water till a clear solution was obtained. To this solution, Polyethylene
Glycol (PEG) 400 and Propylene Glycol (PG) were added as a suitable mixture of plasticizers. This mixture was stirred constantly at $75 \mathrm{rpm}$ on a magnetic stirrer for a period of 2 hours. Further, to the resultant homogeneous solution, weighed quantities of drug loaded nanoparticles dispersed in water were added. The resulting homogeneous solution was then poured carefully in a petridish to ensure that the solution spreads uniformly. This was then air dried for a period of 24 hours, following which the patches were carefully scarped and stored in an airtight plastic cover. A backing membrane was prepared by dissolving Ethyl cellulose in a solvent system containing Isopropyl alcohol and acetone in a ratio of 70:30 using dibutyl phthalate as plasticizer [17].

Table 1: Brief description of the screening studies of Mucoadhesive film.

\begin{tabular}{|c|c|c|c|c|c|c|c|c|c|}
\hline \multirow[b]{2}{*}{ Ingredients } & \multicolumn{9}{|c|}{ Formulation Code } \\
\hline & F1 & F2 & F3 & F4 & F5 & F6 & F7 & F8 & F9 \\
\hline \multicolumn{10}{|c|}{ Polymers $(\% \mathrm{w} / \mathrm{w})$} \\
\hline \multirow{3}{*}{$\begin{array}{c}\text { HPMC E15 Lv } \\
\text { PVP K30 } \\
\text { HPMC K4M }\end{array}$} & 5 & & & 10 & 20 & 30 & 10 & 15 & 15 \\
\hline & & 5 & & & & & & & \\
\hline & & & 1 & & & & & & \\
\hline \multicolumn{10}{|c|}{ Plasticizers ( $\% \mathrm{w} / \mathrm{w}$ of the polymer concentration) } \\
\hline \multirow{3}{*}{$\begin{array}{c}\text { PEG } 400 \\
\text { Dibutyl Phthalate } \\
\text { PG }\end{array}$} & & & 20 & 20 & 20 & 20 & 30 & 25 & 25 \\
\hline & 20 & & & & & & & & \\
\hline & & 20 & & & & & & & 15 \\
\hline Water & q.s. & q.s. & q.s. & q.s. & q.s. & q.s. & q.s. & q.s. & q.s. \\
\hline
\end{tabular}

\section{Evaluation of Drug Loaded Nanoparticles Loaded Patches}

a) Appearance of Nanoparticles Loaded Patches: Formulated patches were evaluated for their physical appearance, uniformity, entrapment of any air bubble or precipitation of drug, which on a large part determines patient acceptability of the patch and also therapeutic efficacy [18].

b) Thickness of Nanoparticles Loaded Patches: The thickness of the drug loaded patch is measured at three different points by using a screw gauge and average thickness and standard deviation was determined [19].

c) Folding Endurance of Nanoparticles Loaded Patches: Evaluation of folding endurance involves determining the folding capacity of the patches. Folding endurance is determined by repeatedly folding the patch at the same diameter until it break. The number of times the patch could be folded at the same diameter without breaking is folding endurance value $[20,21]$.

d) Film Weight Variation: The prepared patches are dried at $60^{\circ} \mathrm{c}$ for $4 \mathrm{hrs}$ before testing. A specified area of patch is cut from different parts of the patch and weighed in digital balance. The average weight and standard deviation values are calculated from the individual weights [22].

e) Moisture Uptake Study: A weighed film kept in a desicator at room temperature for $24 \mathrm{~h}$ was taken out and weighed until a constant weight for the film was obtained. The percentage of moisture uptake was calculated as the difference between final and initial weight with respect to initial weight. Results are expressed as mean of 6 determinations [21,22].

f) Drug Content: Transdermal films of specified area (4 $\mathrm{cm} 2$ ) was cut into small pieces and taken into a $50 \mathrm{ml}$ volumetric flask and $20 \mathrm{ml}$ of water was added and allowed to dissolve at room temperature. Then, the volume was made up to $50 \mathrm{ml}$ with water. Similarly, a blank was carried out using a drug-free patch. The solutions were filtered and the drug content was estimated spectro photo metrically [23].

g) In-vitro Disintegration Studies of Nanoparticles Loaded Patches: Disintegration time is the time when an oral film starts breaking when brought in contact with water or 
saliva. Disintegration test was performed by placing the film in the glass Petri dish containing $20 \mathrm{ml}$ of simulated salivary fluid. It was stirred at every $10 \mathrm{~s}$ time interval. The time required for the film to disintegrate was recorded and results are expressed as mean of 6 determinations [24].

h) In-vitro Permeation of Nanoparticles Loaded Patches: The in-vitro permeability of nanoparticles loaded patches was determined to know the extent at which the drug permeates, through the NP's embedded in a patch through an artificial membrane, which in turn is useful to determine the extent to which a permeation enhancer is required to improve the permeation of the drug. Permeability study was performed using modified Franz diffusion cell having $85 \mathrm{ml}$ of capacity. Dialysis membrane (LA 401) having pore size $2.4 \mathrm{~nm}$, molecular weight cut off 12000- 14000 (HIMEDIA) was used. Membrane was activated by soaking membrane in $1 \mathrm{mM}$ solution of EDTA, followed by soaking in $2 \%$ sodium bicarbonate for 20 minutes respectively, then finally soaked in distilled water for 2 hours. Patch was placed between the donor and receptor compartment. Receptor compartment was filled with dialysis medium (phosphate buffer of pH 7.4, $85 \mathrm{ml}$ ). One $\mathrm{ml}$ of 5.5 phosphate buffer was added to the donor compartment. The content of the cell was stirred with the help of magnetic stirrer at $75 \mathrm{rpm}$ at a temperature of $37^{\circ} \mathrm{C}+0.5^{\circ} \mathrm{C}$. At fixed time intervals $(0,1,2,4,8$, $12,24 \mathrm{~h}$ ); $1 \mathrm{ml}$ of the sample was withdrawn from the receiver compartment through side tube. Fresh phosphate buffer of $\mathrm{pH}$ 7.4 was placed to maintain constant volume. Samples were analyzed by UV spectro photometrically using phosphate buffer as blank. Results are expressed as mean of 6 determinations [25].

i) Ex-vivo Permeation of Patches: Ex-vivo permeation studies was carried out to determine the amount of drug getting permeated through the animal buccal mucosa from the nanoparticles loaded patches, using a Franz diffusion cell. Freshly excised sheep buccal mucosa was tied to the mouth of modified Franz diffusion cell, filled with $85 \mathrm{ml}$ of phosphate buffer $\mathrm{pH} 7.4$ as receptor media and the patch was placed over it. The content of the cell was stirred with the help of magnetic stirrer at $37^{\circ} \mathrm{C}$ $+0.5^{\circ} \mathrm{C}$ and at $75 \mathrm{rpm}$. One $\mathrm{ml}$ of 5.5 phosphate buffer was added to the donor compartment. Samples were collected at regular intervals $(0,1,2,4,8,12$ and 24 hours) for a period of 24 hours from the side tube of receptor compartment, replaced with fresh buffer and analyzed for the drugs spectro photometrically using phosphate buffer as blank. Results are expressed as mean of 6 determinations [26].

j) FTIR (Fourier Transformed Infrared) Studies: Integrity of pure drugs and nanoparticles loaded patches was checked by taking an IR spectrum. The spectra were obtained using Shimadzu FTIR- 8700 spectrophotometer. In this study, potassium bromide $(\mathrm{KBr})$ disc method was employed. Before forming the disc of potassium bromide, it was completely dried at $100^{\circ} \mathrm{C}$ for one hour and then cooled following which it was thoroughly mixed with the sample in the ratio of 1 part of sample and 100 parts of $\mathrm{KBr}$. The mixture was compressed to form a disc using dies under very high pressure and compression force. This disc was placed in the sample chamber and a spectrum was obtained through the software program which was further subjected to interpretation [27].

k) Cellular Uptake of the Nanoparticles From The Patches: The cell lines used for the cellular uptake of the nanoparticles from the patches were A431, which are epidermoid carcinoma cell lines of Homo sapiens (ATCC cat. No: ATCC CRL-1555). These cell lines were stored in Dulbecco's Modified Eagle Medium (DMEM) media supplemented with 10\% FBS and 1\% Pen Strep. A431 cells were grown in P-35 cell culture treated dishes using DMEM complete media until confluent. The cell monolayer was washed twice with sterile $1 \mathrm{X}$ PBS followed by incubation with coumarin- 6 conjugated nanoparticles loaded patches at $0.1 \mathrm{mg}$ / $\mathrm{ml}$ for different time points $(3 \mathrm{hr}, 6 \mathrm{hr}, 12 \mathrm{hr}$, and $24 \mathrm{hr}$ ). Post incubation, the cells were harvested at specific time points and washed twice using 1X PBS. The cells were then centrifuged at 2000rpm for 3 mins and pellet was suspended using $500 \mu \mathrm{l}$ of $1 \mathrm{X}$ PBS. The cells are analysed using BD FACS Calibur. The images were taken using Fluorescent microscope [28].

\section{Results and Discussion}

A significant property of the mucoadhesive layer should be able to adhere to the mucosal surface even after drug loading. The research involved screening of various polymers and plasticizers for the formulation of mucoadhesive portion, which narrowed down to HPMC E15 Lv in a concentration of $15 \% \mathrm{w} / \mathrm{w}$ as the core polymer, along with PEG $400(25 \% \mathrm{w} / \mathrm{w})$ and PG $(15 \% \mathrm{w} / \mathrm{w})$ as the plasticizers. Backing membrane is most important parts for unidirectional release patches as it protects the mucoadhesive layer by getting eroded due to the salivary fluids and also provides a support system for the mucoadhesive portion. Ethyl cellulose at the concentration of $5 \% \mathrm{w} / \mathrm{w}$ was used as polymer along with DBP as plasticizer to formulate a flexible and thin backing membrane which was also strong enough to support the mucoadhesive film.

The evaluation of the patches of individual drug loaded nanoparticles was conducted and the results of the same are given in Table 2. The appearance of the patches was found to be smooth and white coloured showing homogenously dispersed drug loaded nanoparticles. The thickness of the patches was found to be in the range of $0.28 \mathrm{~mm}$ to $0.34 \mathrm{~mm}$ which is desirable. The weight variation of the patches was found to be in the limits and the drug content was above 95\%. Folding endurance determines the strength of the patches, which was found to be more than 120 folds. Moisture content was determined by weighing the patches before and after desiccation and it was found in limits. Disintegration time for patches was found to be less than 2 minutes which is highly desirable for buccal mouth dissolving films. 
Table 2: Evaluation of drug loaded nanoparticles loaded Patches.

\begin{tabular}{|c|c|c|c|c|c|c|c|}
\hline Patch & Appearance* & $\begin{array}{l}\text { Thickness } \\
(\mathrm{mm}+\mathrm{SD})^{*}\end{array}$ & $\begin{array}{l}\text { Weight (mg+ } \\
\text { SD)* }\end{array}$ & $\begin{array}{l}\text { Drug content } \\
(\%)^{*}\end{array}$ & $\begin{array}{c}\text { Folding } \\
\text { endurance } \\
\text { (folds+SD)* }\end{array}$ & $\begin{array}{c}\text { \%Moisture } \\
\text { content } \\
\text { (\%)* }\end{array}$ & $\begin{array}{c}\text { In-vitro } \\
\text { disintegration } \\
\text { Time (sec+SD)* }\end{array}$ \\
\hline NEV-PATCH & $\begin{array}{c}\text { White coloured } \\
\text { patch showing } \\
\text { homogenously } \\
\text { dispersed drug } \\
\text { loaded nanoparticles }\end{array}$ & $0.29+0.01$ & $0.19+0.08$ & $98.75+0.2$ & $120+2$ & 2.8 & $120+2$ \\
\hline LAM-PATCH & $\begin{array}{l}\text { White coloured } \\
\text { patch showing } \\
\text { homogenously } \\
\text { dispersed drug } \\
\text { loaded nanoparticles }\end{array}$ & $0.3+0.02$ & $0.20+0.02$ & $97.22+0.1$ & $122+6$ & 3.6 & $122+6$ \\
\hline STA-PATCH & $\begin{array}{l}\text { White coloured } \\
\text { patch showing } \\
\text { homogenously } \\
\text { dispersed drug } \\
\text { loaded nanoparticles }\end{array}$ & $0.33+0.01$ & $0.25+0.01$ & $98.21+0.8$ & $124+5$ & 2.5 & $124+5$ \\
\hline ISO-PATCH & $\begin{array}{l}\text { White coloured } \\
\text { patch showing } \\
\text { homogenously } \\
\text { dispersed drug } \\
\text { loaded nanoparticles }\end{array}$ & $0.32+0.05$ & $0.24+0.04$ & $97.11+0.7$ & $120+3$ & 2.1 & $120+3$ \\
\hline
\end{tabular}

In-vitro Drug Release and Ex-Vivo Drug Permeation Study

In-vitro drug release and ex-vivo permeation studies of all the patches can be very well correlated and was found to be significant. As seen in Figure 2, the amount of pure drugNevirapine permeated through the buccal patch was as low as $20 \%$ at the end of 24 hours, while the in-vitro release of drug from the patch showed more than $80 \%$ in the same period of time. Drug permeation from the patch exhibited $80 \%$, which was a significant increase in the amount of drug available for the anti-retro viral therapy. As seen in Figure 3, the amount of pure drug- Stavudine permeated through the buccal patch was less than $20 \%$ at the end of 24 hours, while the in-vitro release of drug from the patch showed more than $80 \%$ in the same period of time. It showed the same amount of drug release in 12 hours which was sustained till 24 hours. Permeation of Stavudine was comparatively slow but exhibited $80 \%$ drug release by the end of 24 hours, which can be considered as a substantial increase in the amount of drug available for the treatment.

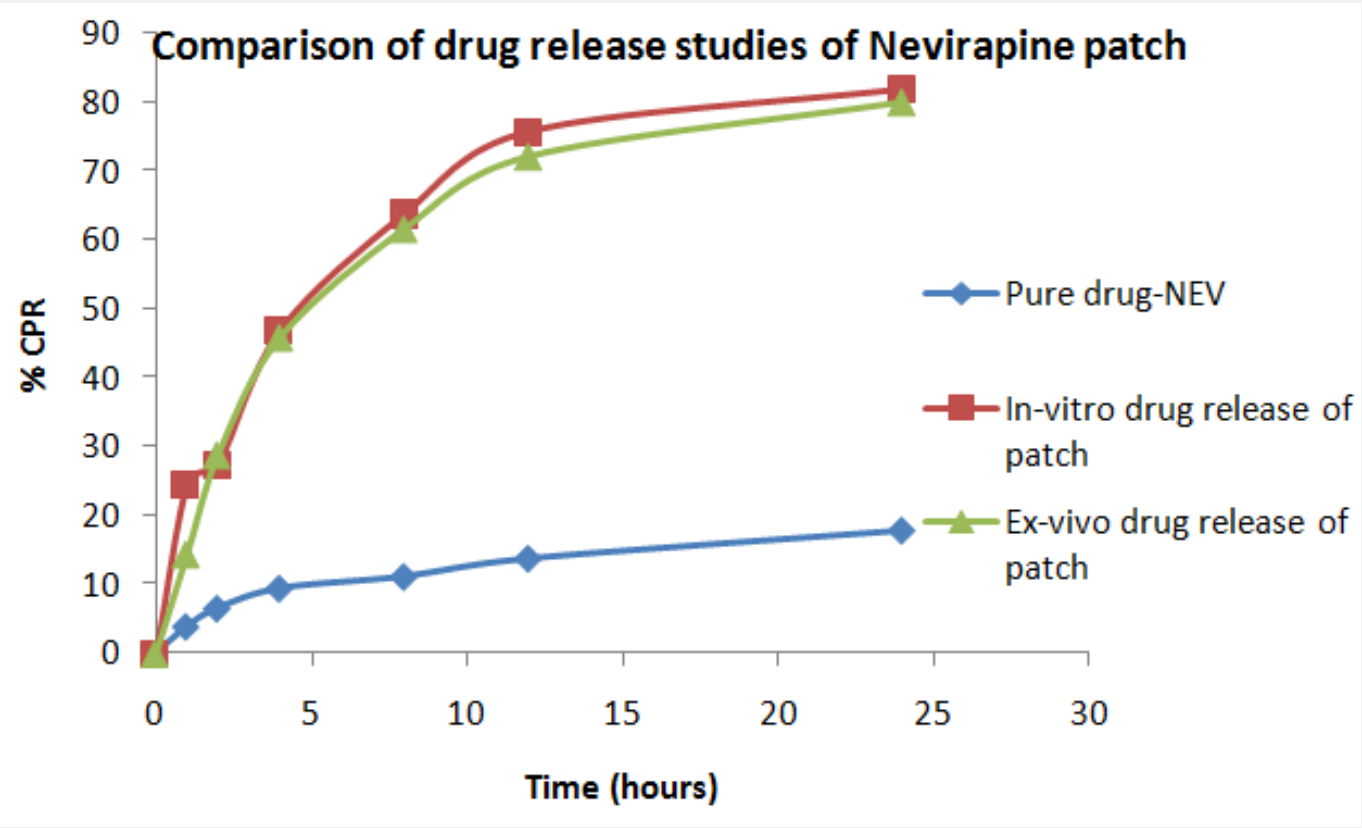

Figure 2: Comparison of drug release studies of Nevirapine patch. 


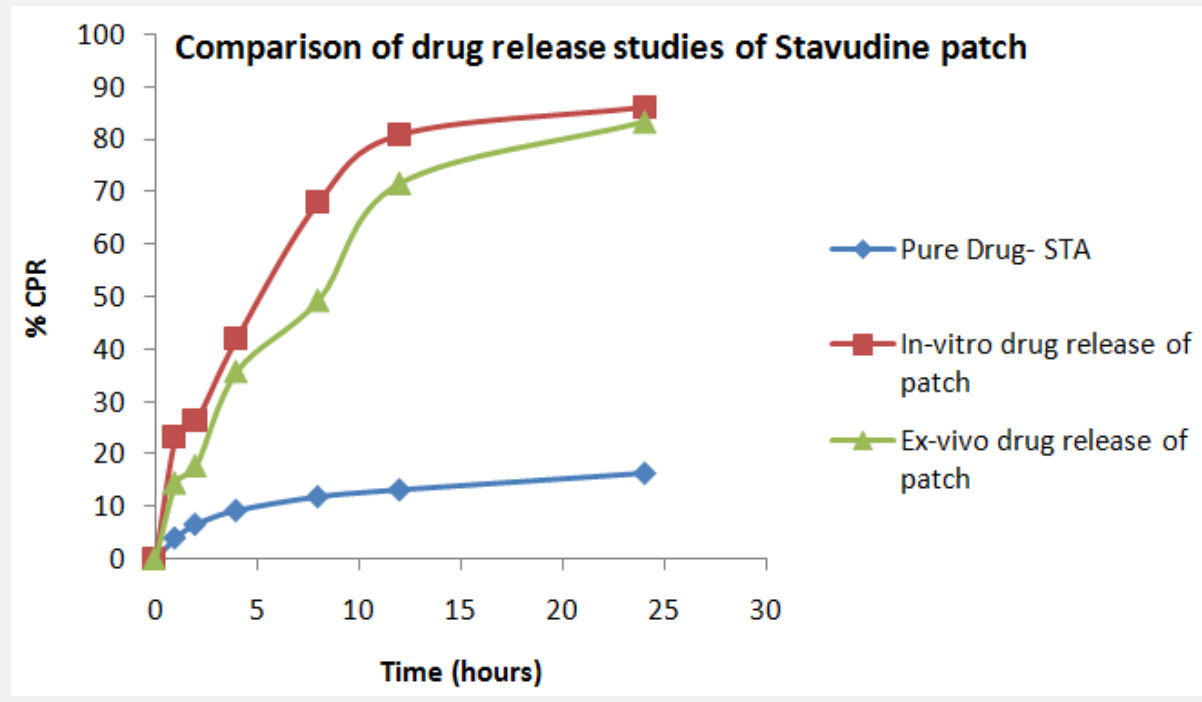

Figure 3: Comparison of drug release studies of Stavudine patch.

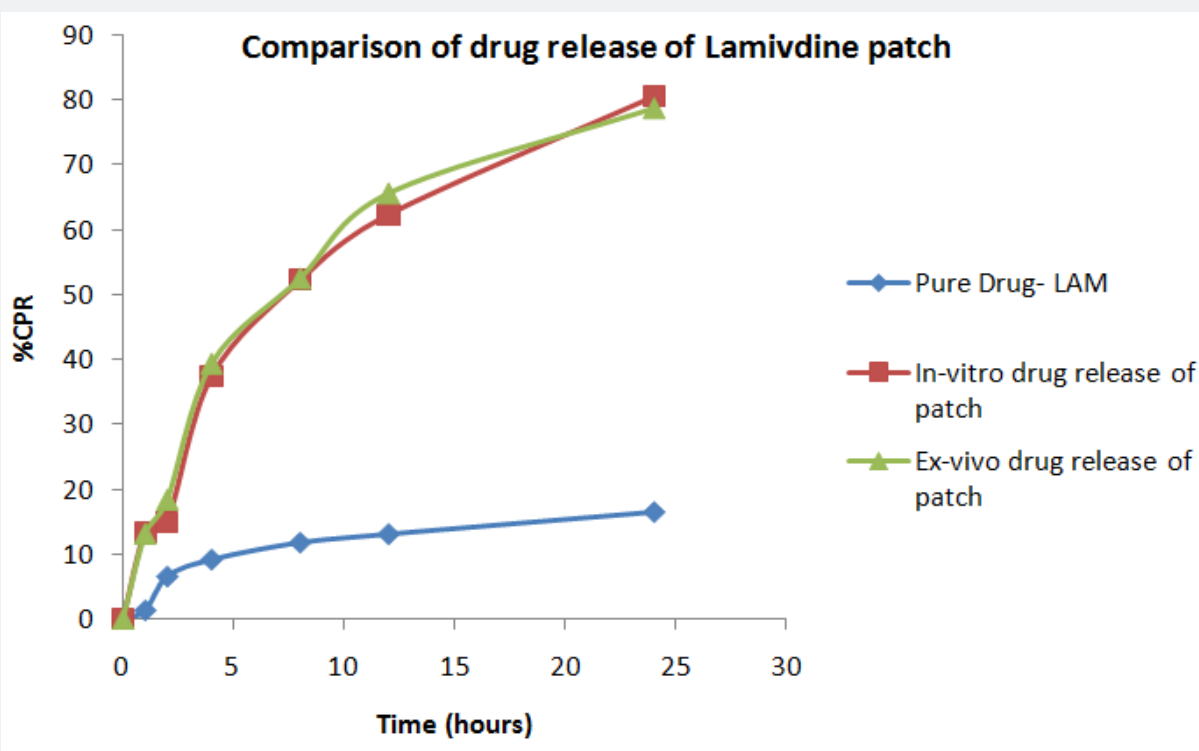

Figure 4: Comparison of drug release studies of Lamivudine patch.

As seen in Figure 4, the amount of pure drug-Lamivudine permeated through the buccal patch was $15 \%$ at the end of 24 hours, while the in-vitro release of drug from the patch showed $80 \%$ in the same period of time. The amount of drug release from the patch was gradual and a similar pattern was observed in the ex-vivo permeation of the drug. However, the drug permeated through the buccal mucosa was as high as $70 \%$ only. This increase of drug permeated was found to be considerable as compared to the pure drug- Lamivudine. As seen in Figure 5, the amount of pure drug-Isoniazid permeated through the buccal patch was as low as $12 \%$ at the end of 24 hours, while the in-vitro release of drug from the patch showed more than $80 \%$ in the same period of time. Drug permeation from the patch exhibited $80 \%$, which was a significant increase in the amount of drug available for the anti-tuberculosis therapy.

\section{FT-IR of Drugs and Nanoparticles Loaded Patches}

FTIR spectra of the pure drugs were compared with their respective nanoparticles loaded patches. By comparing the FTIR spectra, it was observed that there was no considerable difference in their spectral values. This was justified by the presence of the characteristic peaks of the pure drugs in their Nano formulations as given in Table 3 and showed in Figures 6-9. Since there is no considerable change in the position of the bands, it can be concluded that the drugs maintained their identity without undergoing any interaction. 


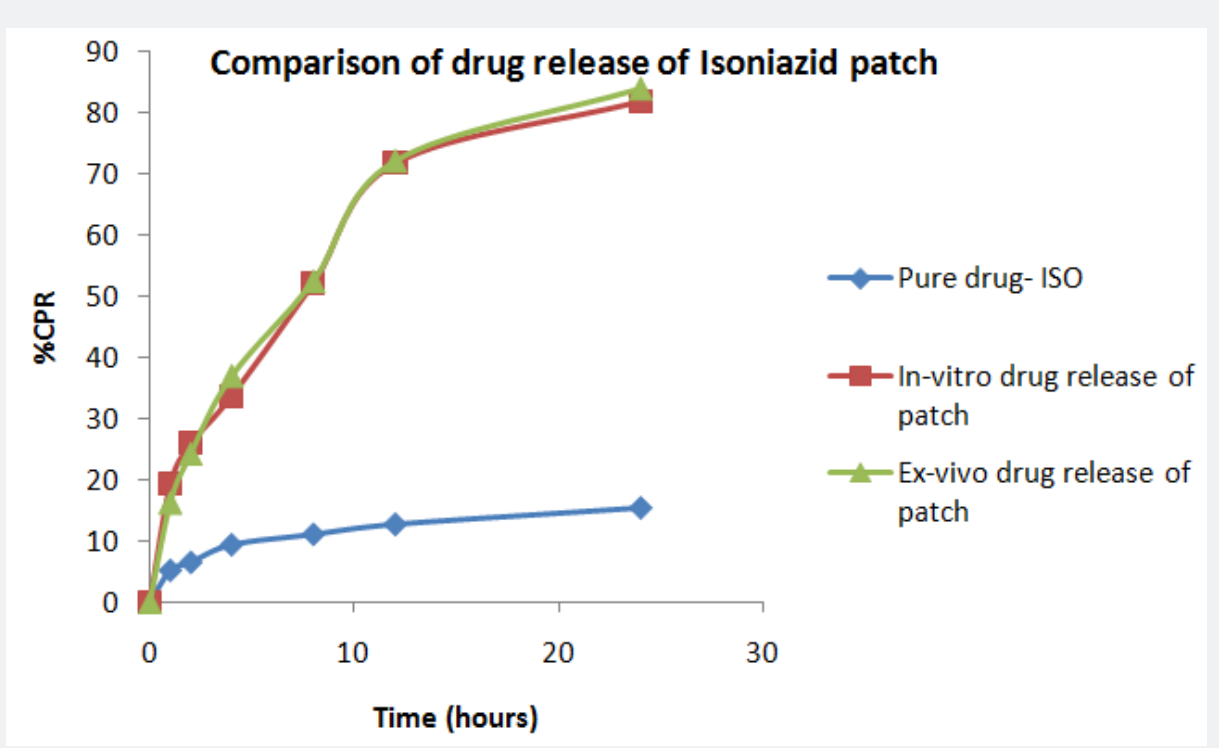

Figure 5: Comparison of drug release studies of Isoniazid patch.

Table 3: Details of FT- IR peaks of drugs and nanoparticles loaded patches.

\begin{tabular}{|c|c|c|c|c|c|c|c|c|c|c|c|}
\hline \multicolumn{12}{|c|}{ Details of IR peaks $\left(\mathrm{cm}^{-1}\right)$} \\
\hline \multicolumn{3}{|c|}{ Nevirapine } & \multicolumn{3}{|c|}{ Stavudine } & \multicolumn{3}{|c|}{ Lamivudine } & \multicolumn{3}{|c|}{ Isoniazid } \\
\hline $\begin{array}{l}\text { Pure } \\
\text { drug }\end{array}$ & Patch & Group & $\begin{array}{l}\text { Pure } \\
\text { drug }\end{array}$ & Patch & Group & Pure drug & Patch & Group & $\begin{array}{l}\text { Pure } \\
\text { drug }\end{array}$ & Patch & Group \\
\hline 3059 & 3061 & $=\mathrm{C}-\mathrm{H}$ & 1647 & 1633 & $=\mathrm{C}=\mathrm{O}$ & 3327.45 & 3397 & $-\mathrm{N}-\mathrm{H}$ & 1059 & 1060 & $=\mathrm{C}=\mathrm{O}$ \\
\hline 1241 & 1245 & $-\mathrm{C}=\mathrm{N}$ & 3042 & 2923 & $=\mathrm{C}-\mathrm{H}$ & 3208 & 3217 & $(-\mathrm{O}-\mathrm{H})$ & 2855 & 2951 & $=\mathrm{C}-\mathrm{H}$ \\
\hline 3188 & 3190 & $\mathrm{CONH}_{2}$ & 3425 & 3434 & $\mathrm{CONH}_{2}$ & 1649.38 & 1651 & $\mathrm{CONH}_{2}$ & 1667 & 1667 & $=\mathrm{C}=\mathrm{O}$ \\
\hline & & & & & & & & & 1355 & 1333 & $-C=N$ \\
\hline
\end{tabular}

\section{Cellular Uptake of Nanoparticles from Patches}

Coumarin-6 is popularly used as a fluorescence marker for confocal microscopic observation due to its high fluorescence intensity. Coumarin-6-loaded fluorescent nanoparticles were prepared to demonstrate the cellular uptake and bio distribution of the positively charged Eudragit nanoparticles in A431 cells, which were monitored using a flow cytometer and a confocal microscope. The fluorescence images of the cellular uptake of the drugs from the patches at different time points are shown in Figures $10,12,14,16$. The amount of fluorescence intensity indicative of the amount of increase in no. of cells been up taken with the increase in the time is depicted in Figures 11,13,15,17 and in Table 4. The strong green fluorescence indicated that the nanoparticles were internalized and localized in the cytoplasm of the cells. Figure 18 clearly indicates the increase in the amount of fluorescence intensity for individual patches with the increase in time and hence it is indicative of a better drug delivery system for the treatment of AIDS and tuberculosis in the paediatric population.

\section{Conclusion}

HIV stigma and related opportunistic infection namely tuberculosis are major barriers for a healthy society. Adherence to HIV care for children and its treatment becomes more difficult as the regimen for the therapy involves multiple drugs which are needed to be administered regularly to children, a population opposing any medication. Hence, the present research study resulted in the solution to the problem by the development of patient friendly dosage forms and achieved the disease mitigation in a more effective manner. The paediatric buccal films prepared in the present research not only cater the need of preparing a patient friendly dosage form but are technologically highly superior as compared to the other commercially available 
dosage forms in terms of accurate dosing and decrease in dosing frequency thus resulting in improved patient compliance to therapy. All the technological parameters indicate that the nanoparticles loaded patches are very strong, stable; highly mucoadhesive disintegrates within 120 seconds and provides desired drug release for a period of 24 hours. The cellular uptake studies revealed that sufficient number of drug loaded nanoparticles have been up taken by A431 cell lines which mimic the outer layer of the buccal mucosa. Further, cell line studies support the effective controlled drug release from the developed films ensuring therapeutic drug concentration for prolonged period of time and thus overcoming the inherent problems of the drugs like t-half and bioavailability.

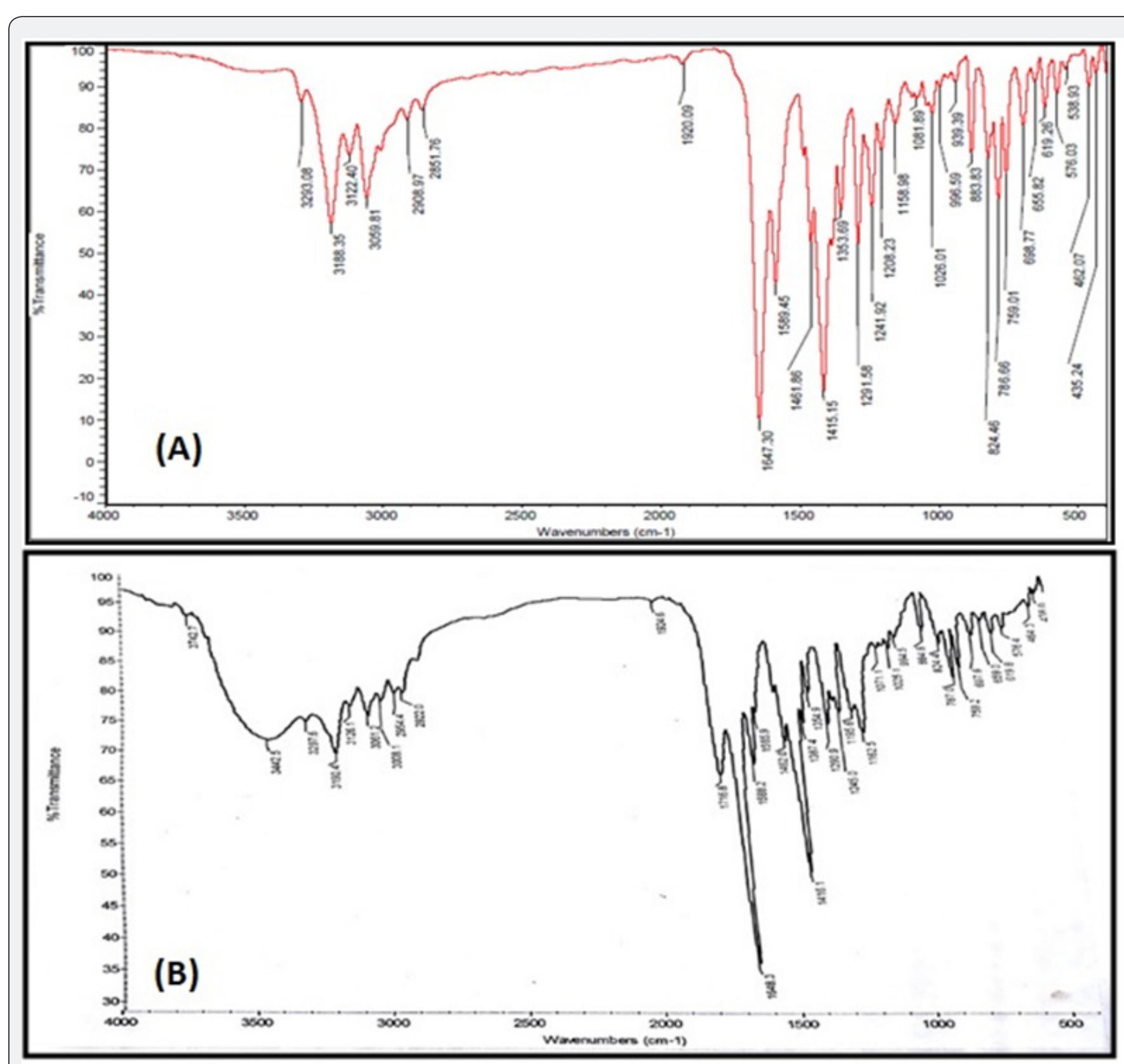

Figure 6: FT-IR peaks of (A) Nevirapine and (B) Nanoparticles loaded patches of Nevirapine. 


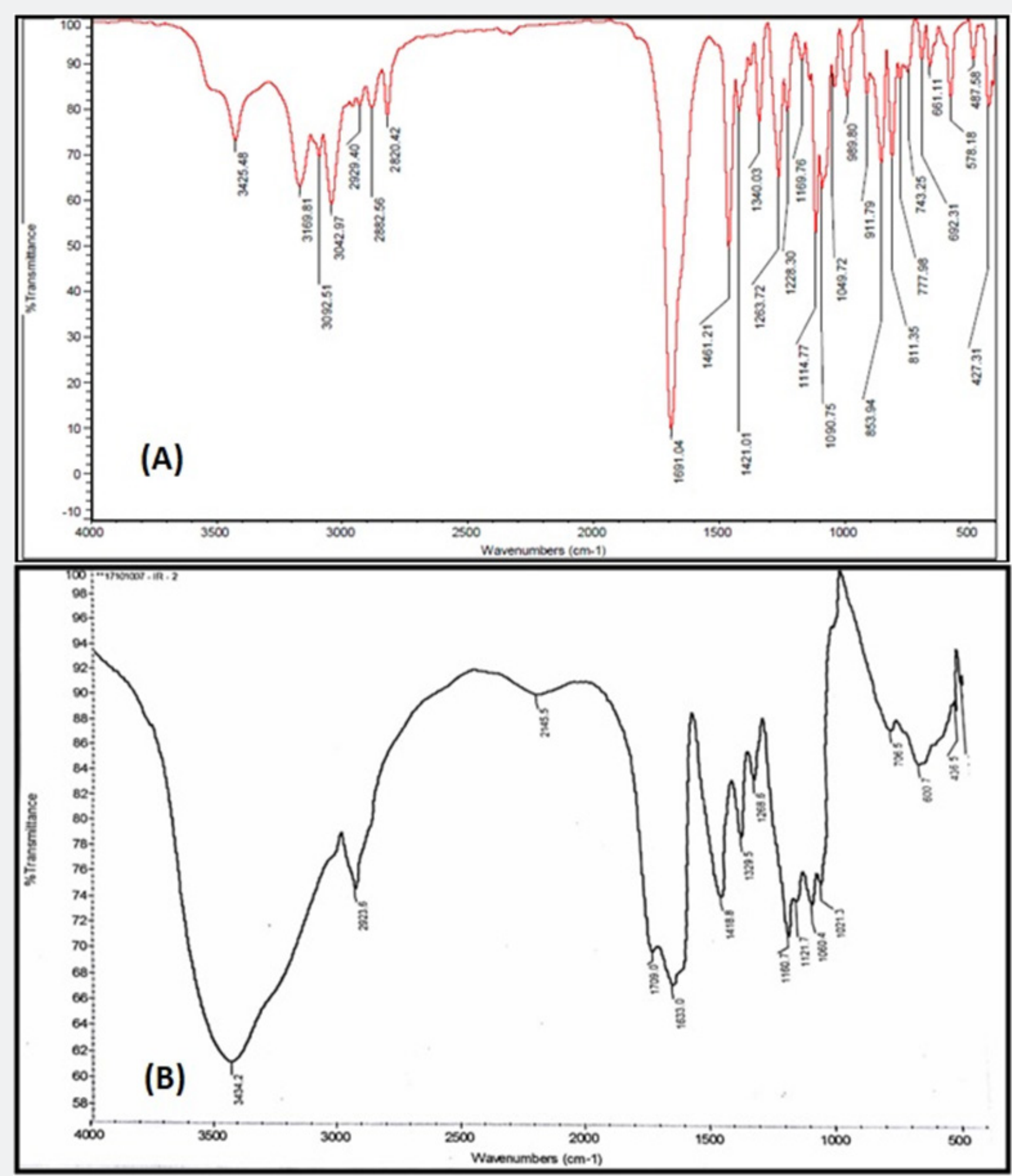

Figure 7: FT-IR peaks of (A) Stavudine and (B) Nanoparticles loaded patches of Stavudine. 

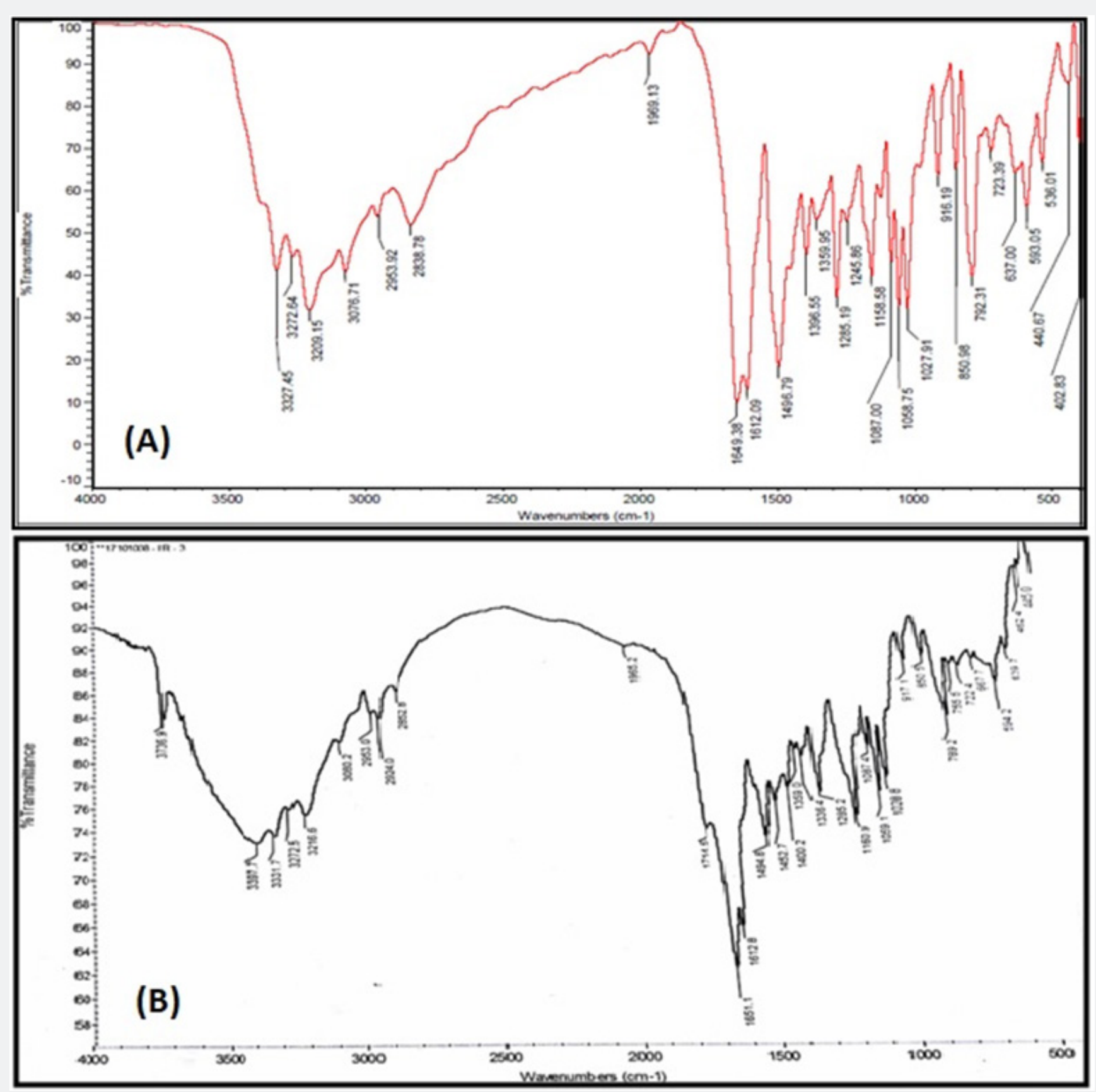

Figure 8: FT-IR peaks of (A) Lamivudine and (B) Nanoparticles loaded patches of Lamivudine. 

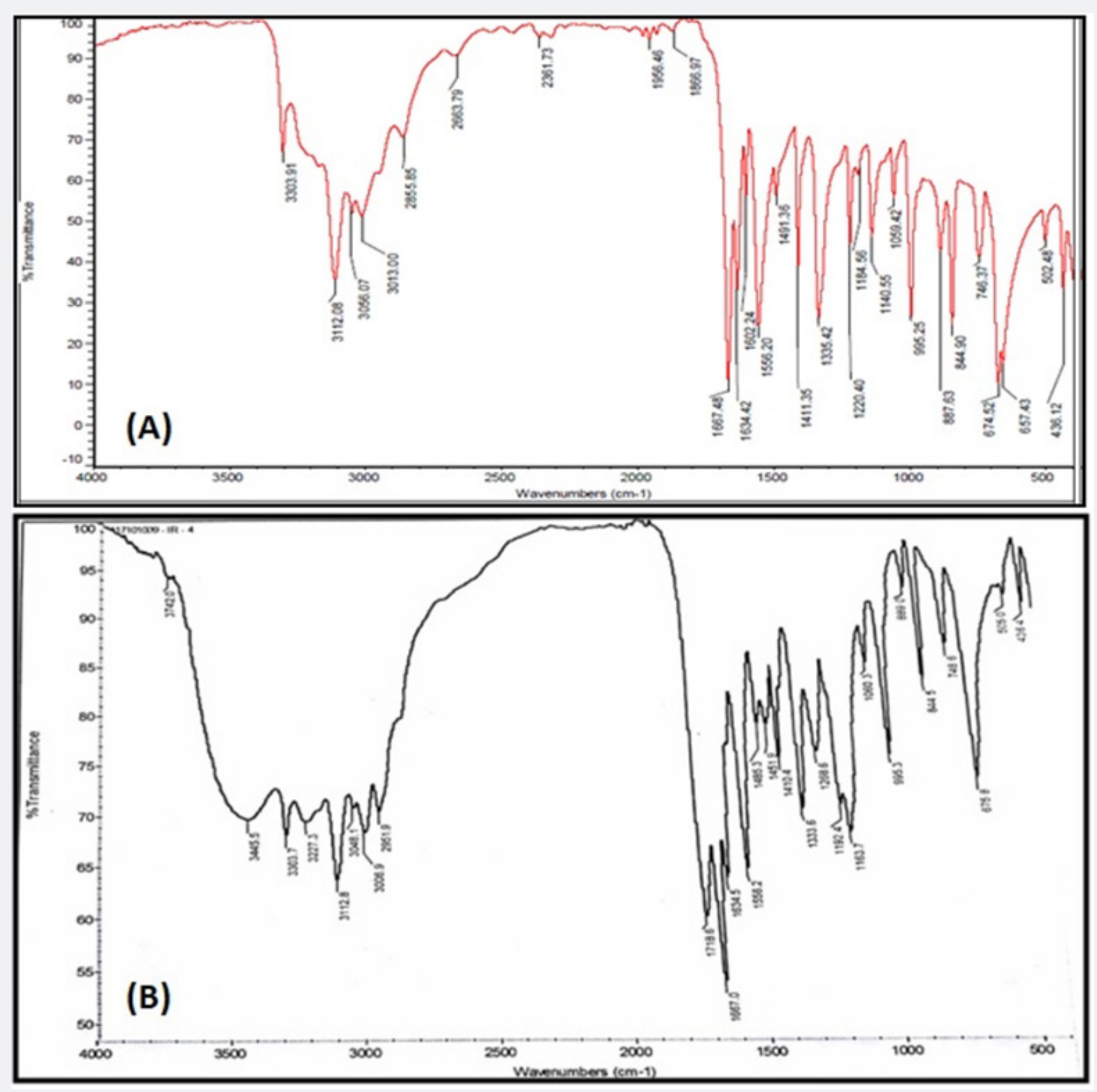

Figure 9: FT-IR peaks of (A) Isoniazid and (B) Nanoparticles loaded patches of Isoniazid. 


\section{Novel Approaches in Drug Designing \& Development}

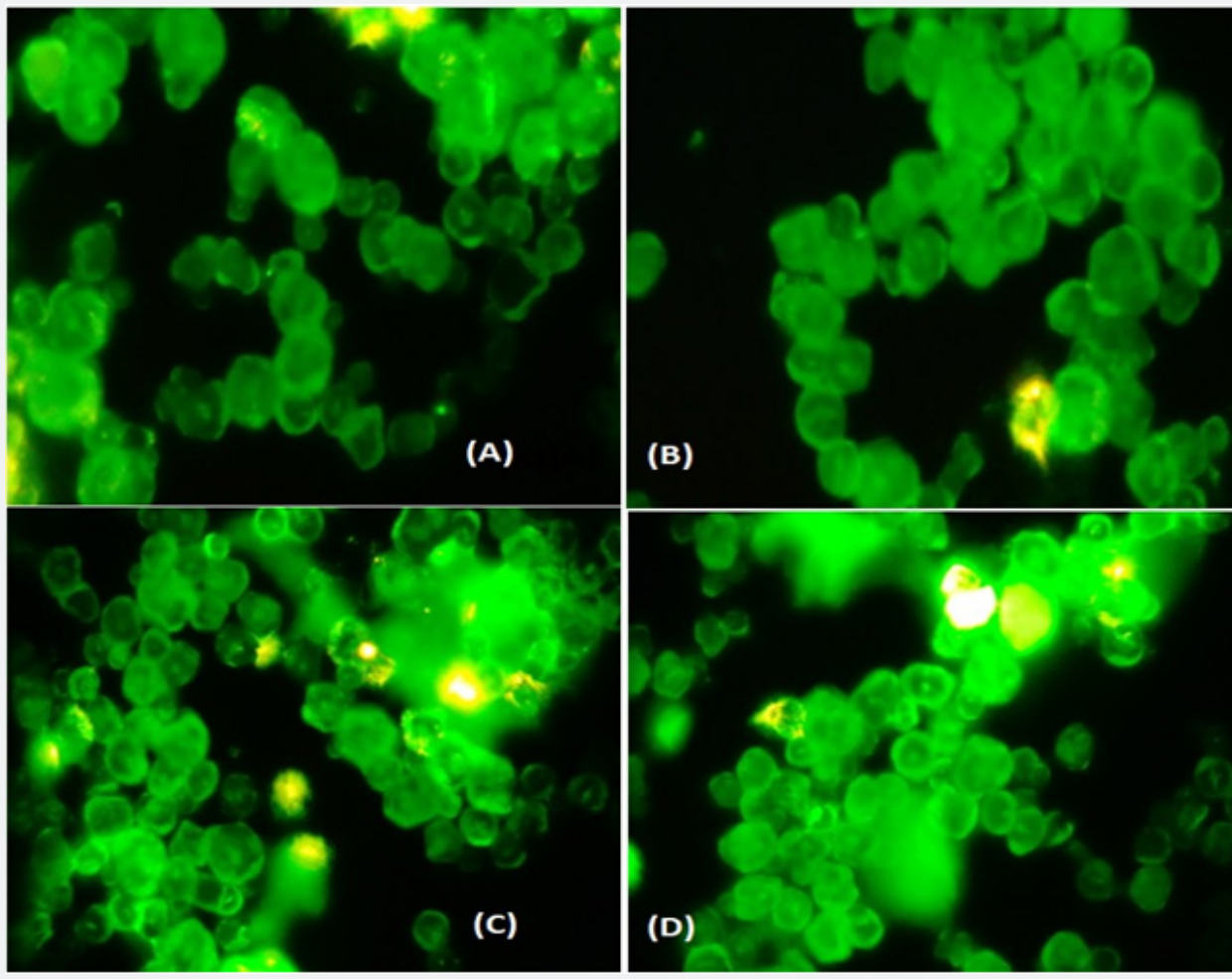

Figure 10: Fluorescence images of Cellular uptake of nevirapine from the patches with respect to time (A) at 3 hours, (B) at 6 hours, (C) at 12 hours $(D)$ at 24 hours.

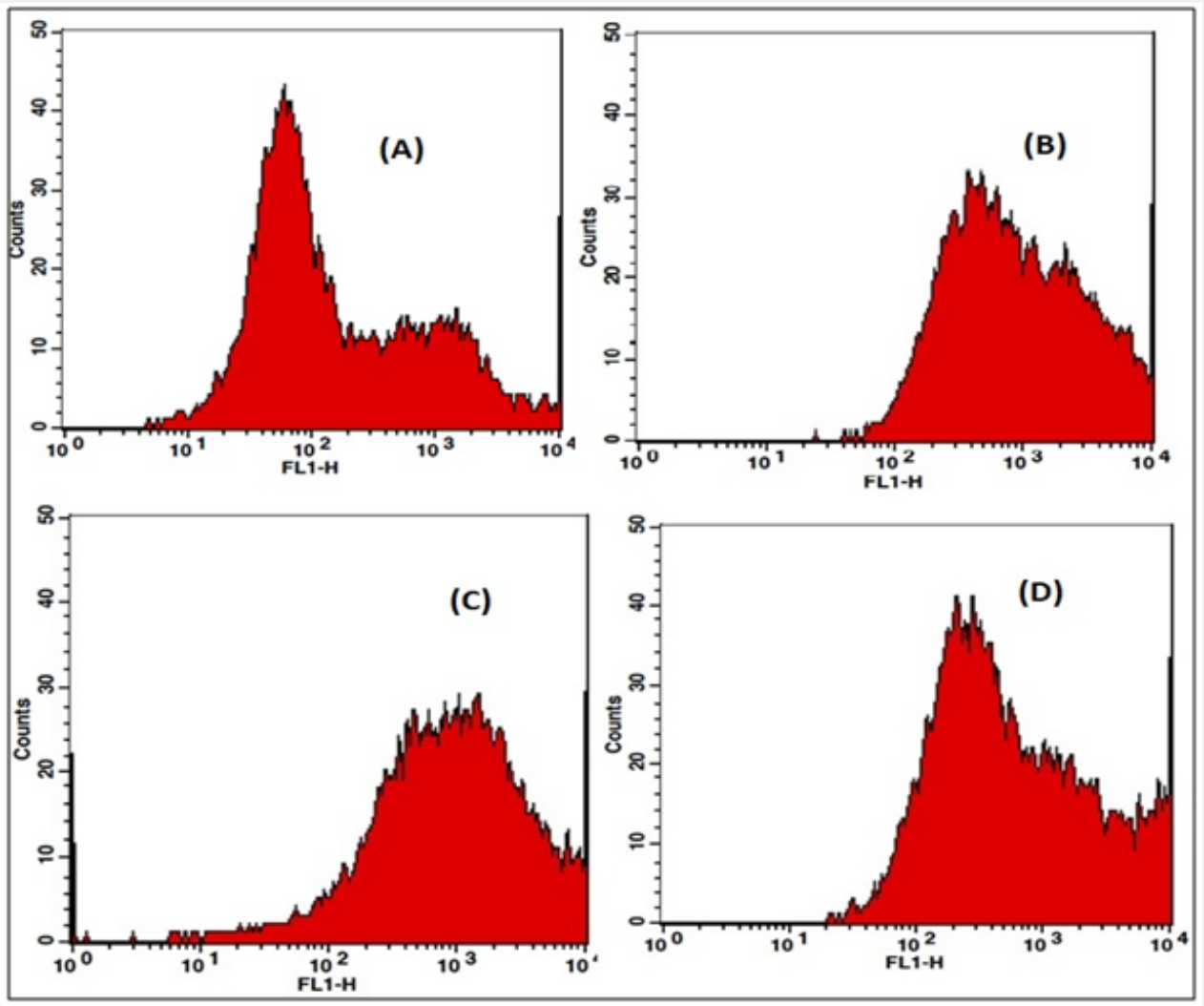

Figure 11: 2 D plots of Flow Cytometry of Nevrapine from the patches (A) at 3 hours, $(B)$ at 6 hours, (C) at 12 hours (D) at 24 hours. 

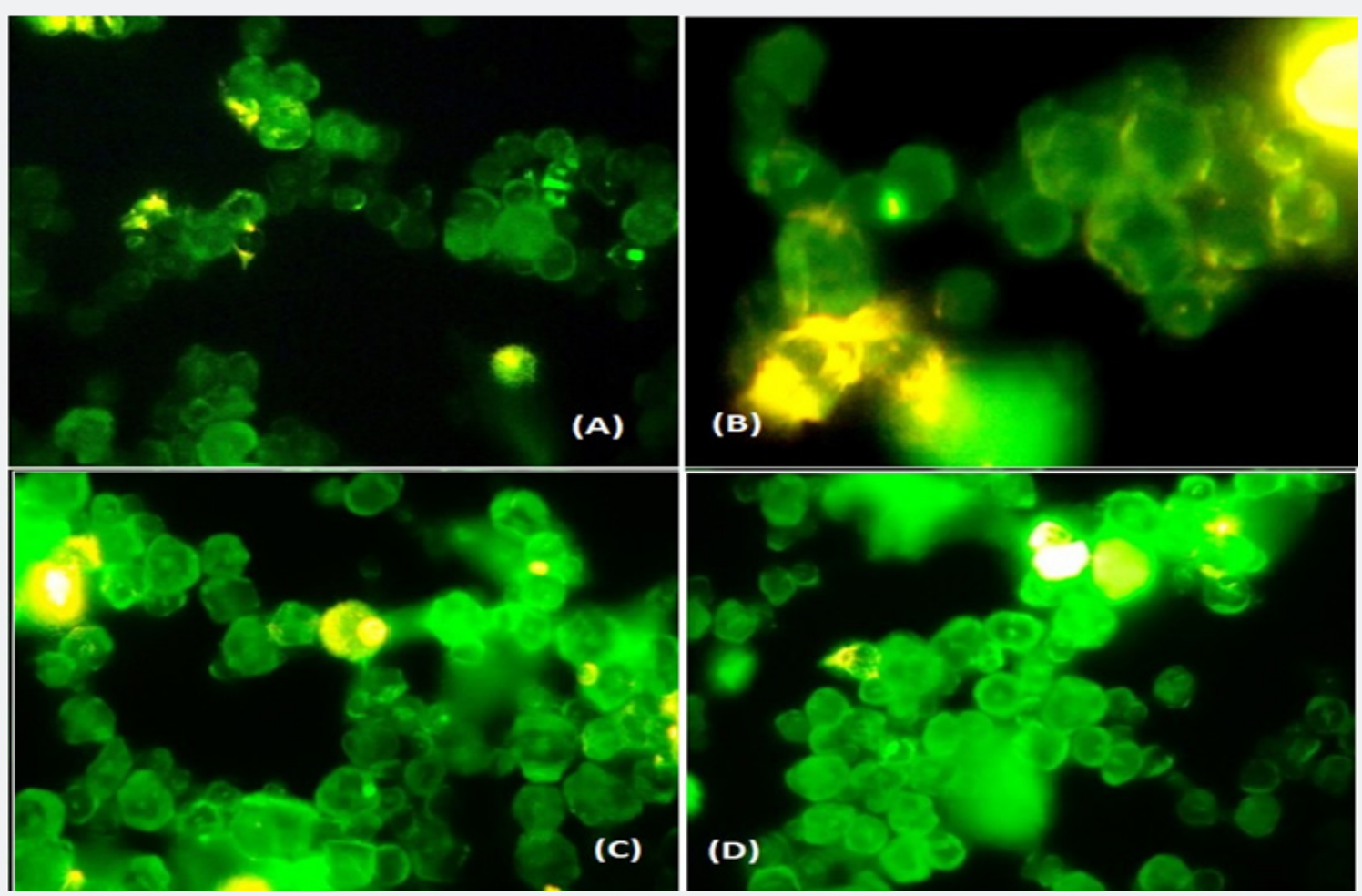

Figure 12: Fluorescence images of Cellular uptake of Stavudine from the patches with respect to time (A) at 3 hours, (B) at 6 hours, (C) at 12 hours (D) at 24 hours.
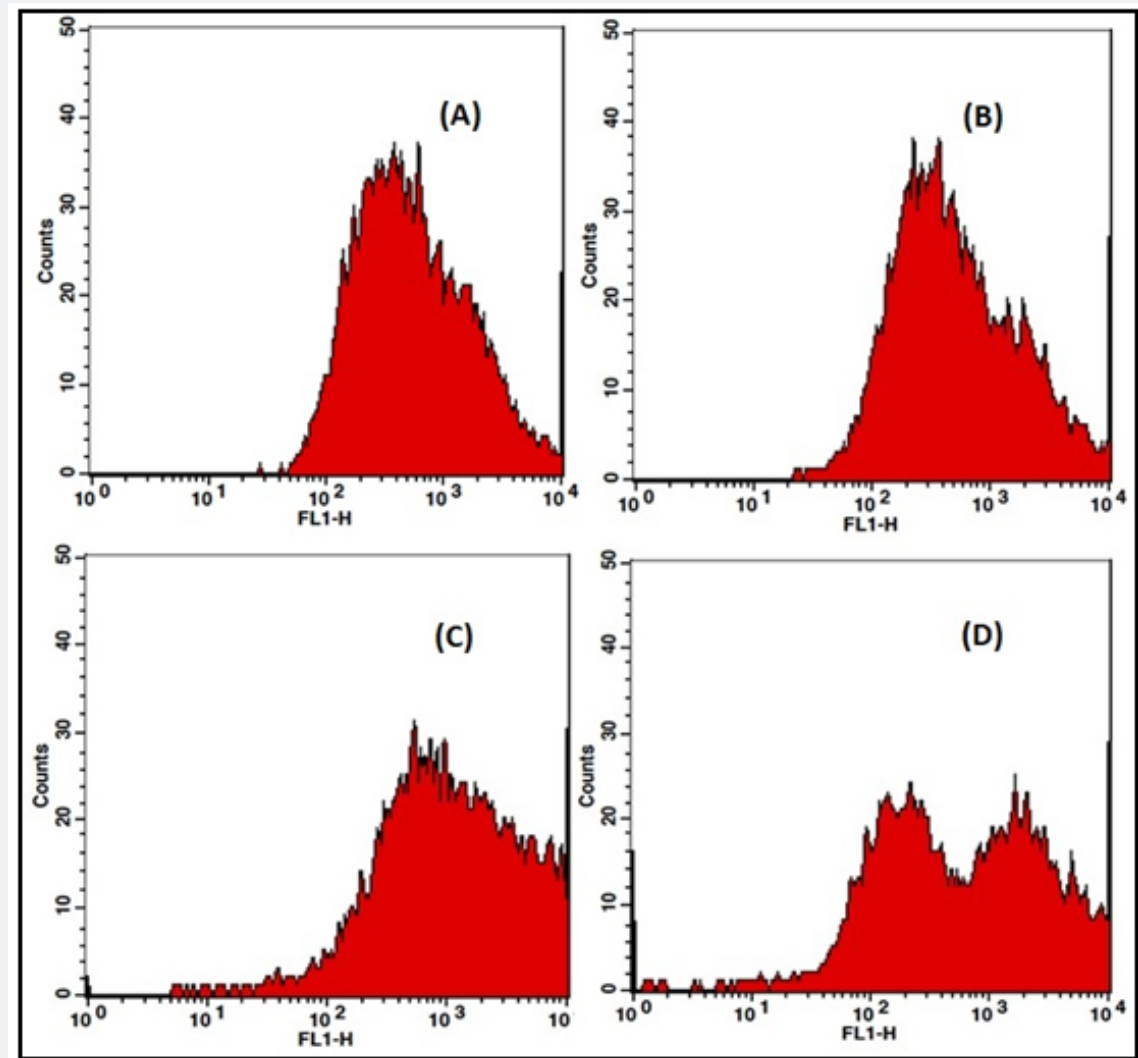

Figure 13: 2 D plots of Flow Cytometry of of Stavudine from the patches (A) at 3 hours, (B) at 6 hours, (C) at 12 hours (D) at 24 hours. 


\section{Novel Approaches in Drug Designing \& Development}
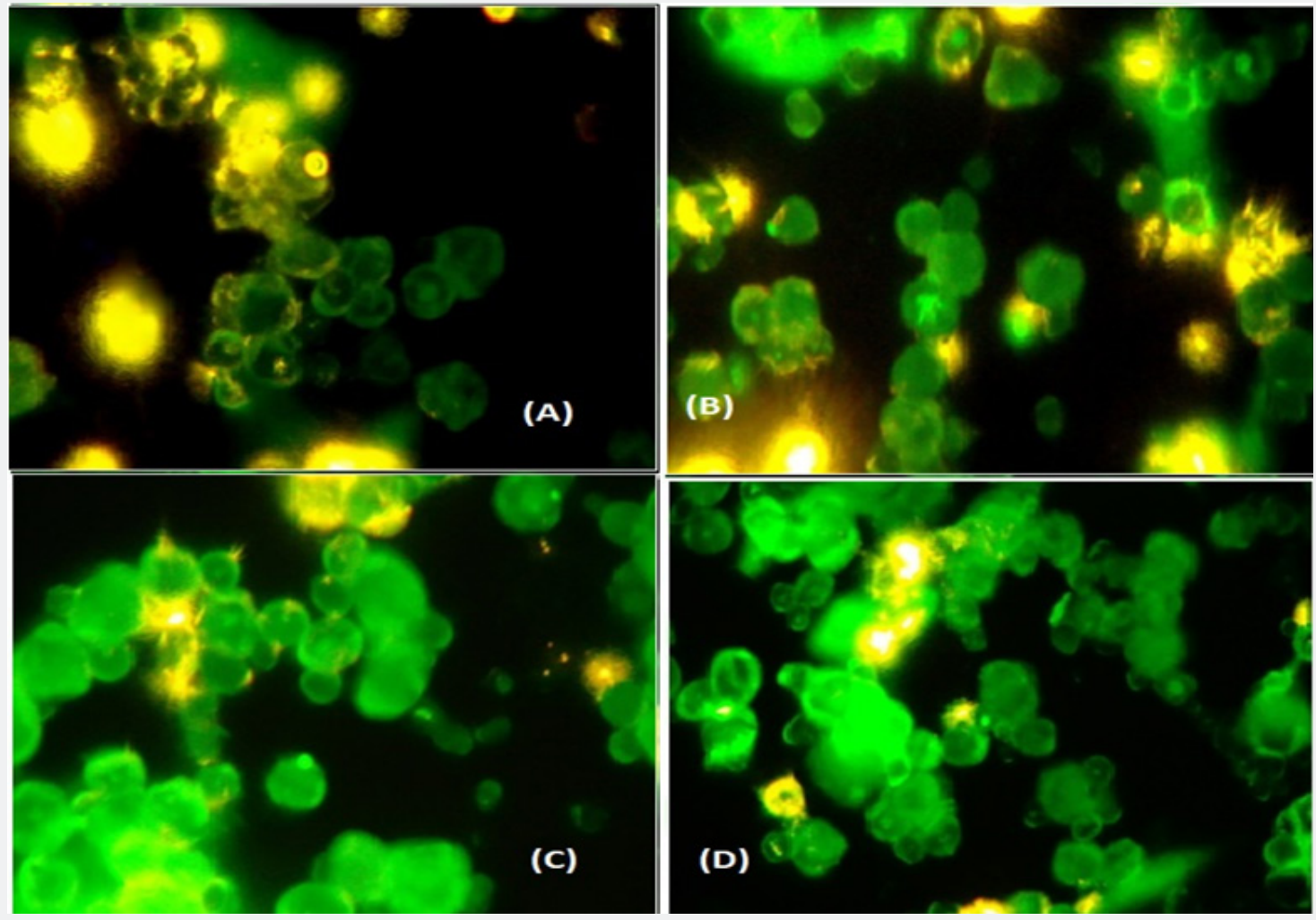

Figure 14: Fluorescence images of Cellular uptake of Lamivudine from the patches with respect to time (A) at 3 hours, (B) at 6 hours, (C) at 12 hours $(D)$ at 24 hours.
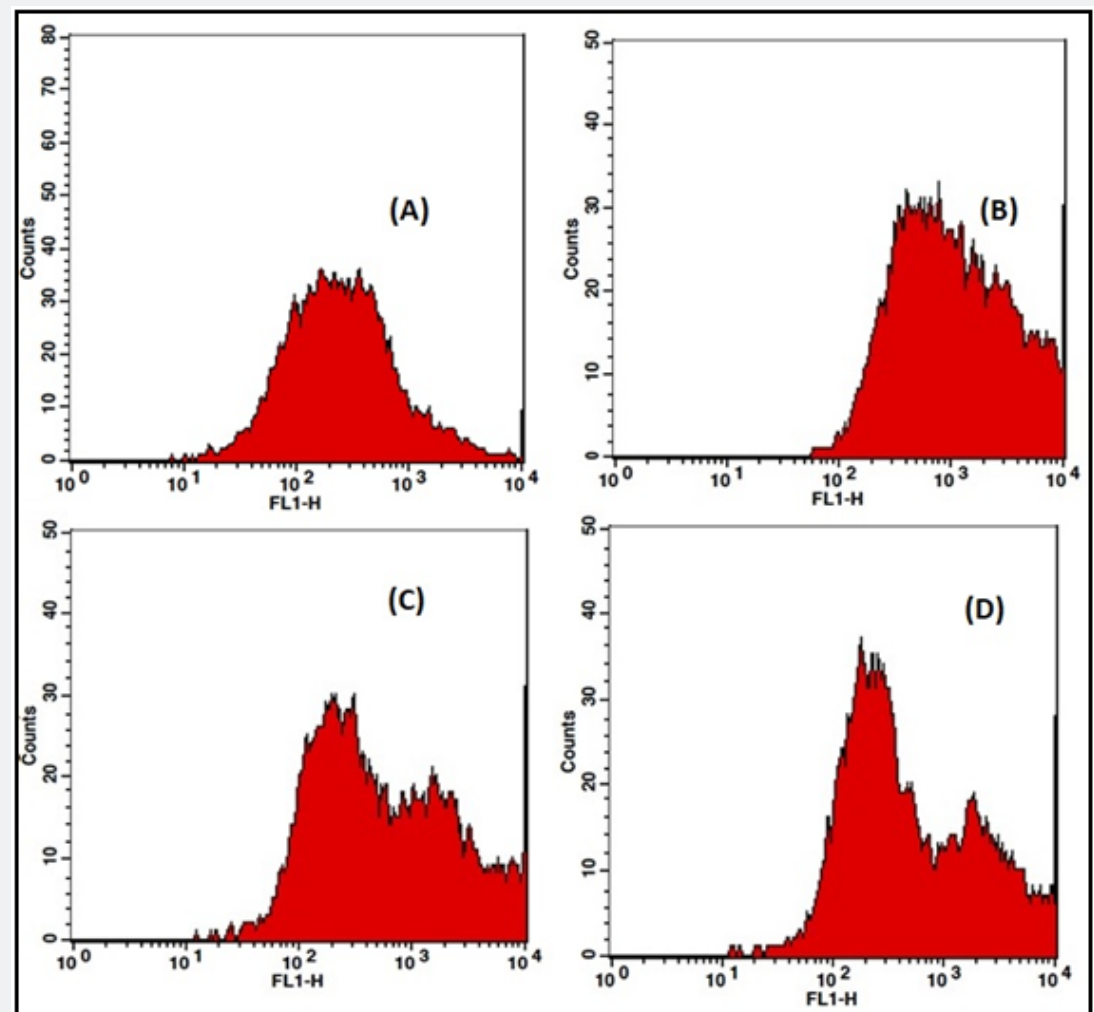

Figure 15: 2 D plots of Flow Cytometry of Lamivudine from the patches (A) at 3 hours, (B) at 6 hours, (C) at 12 hours (D) at 24 hours. 


\section{Novel Approaches in Drug Designing \& Development}

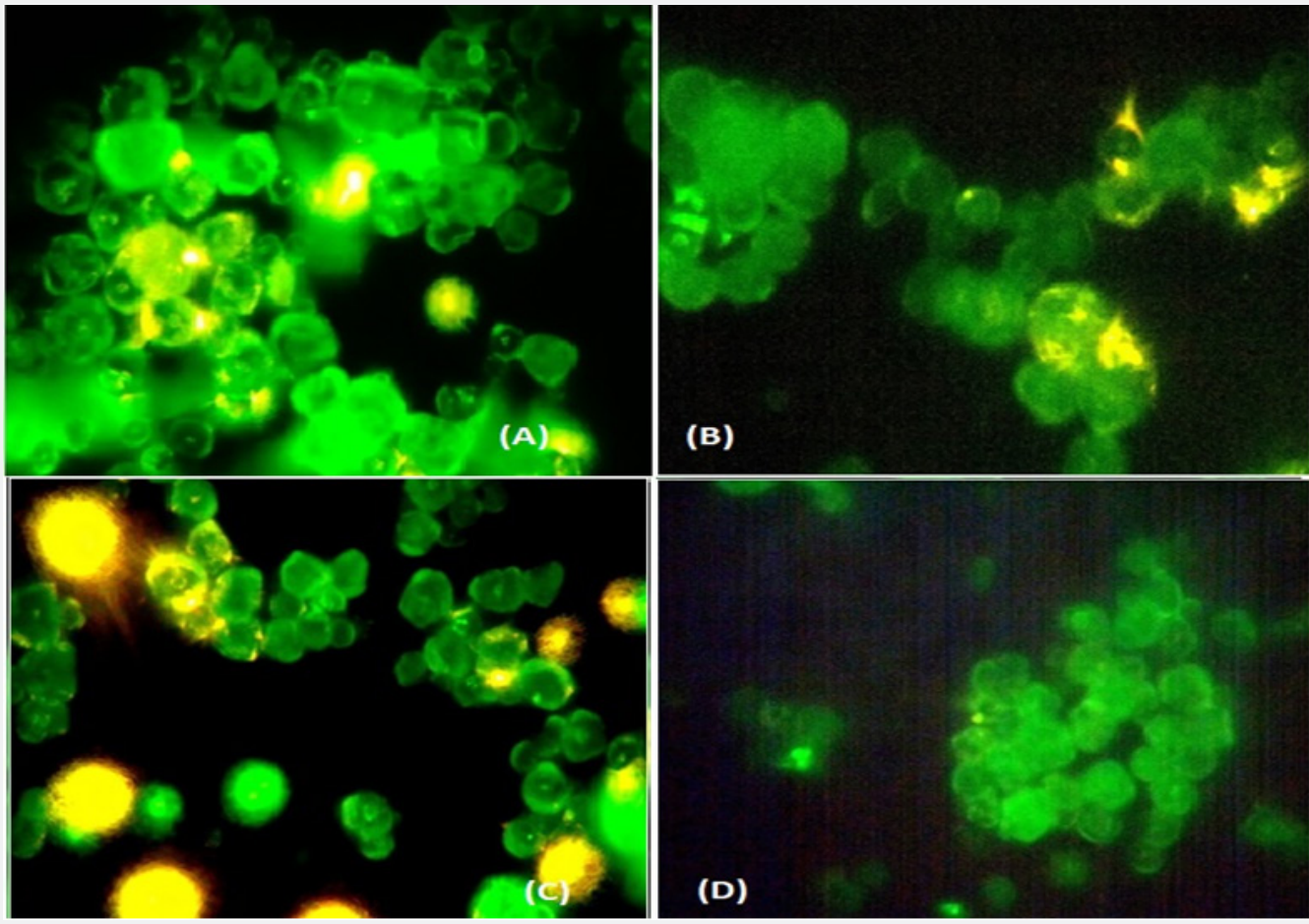

Figure 16: Fluorescence images of Cellular uptake of Isoniazid from the patches with respect to time (A) at 3 hours, (B) at 6 hours, (C) at 12 hours $(D)$ at 24 hours.
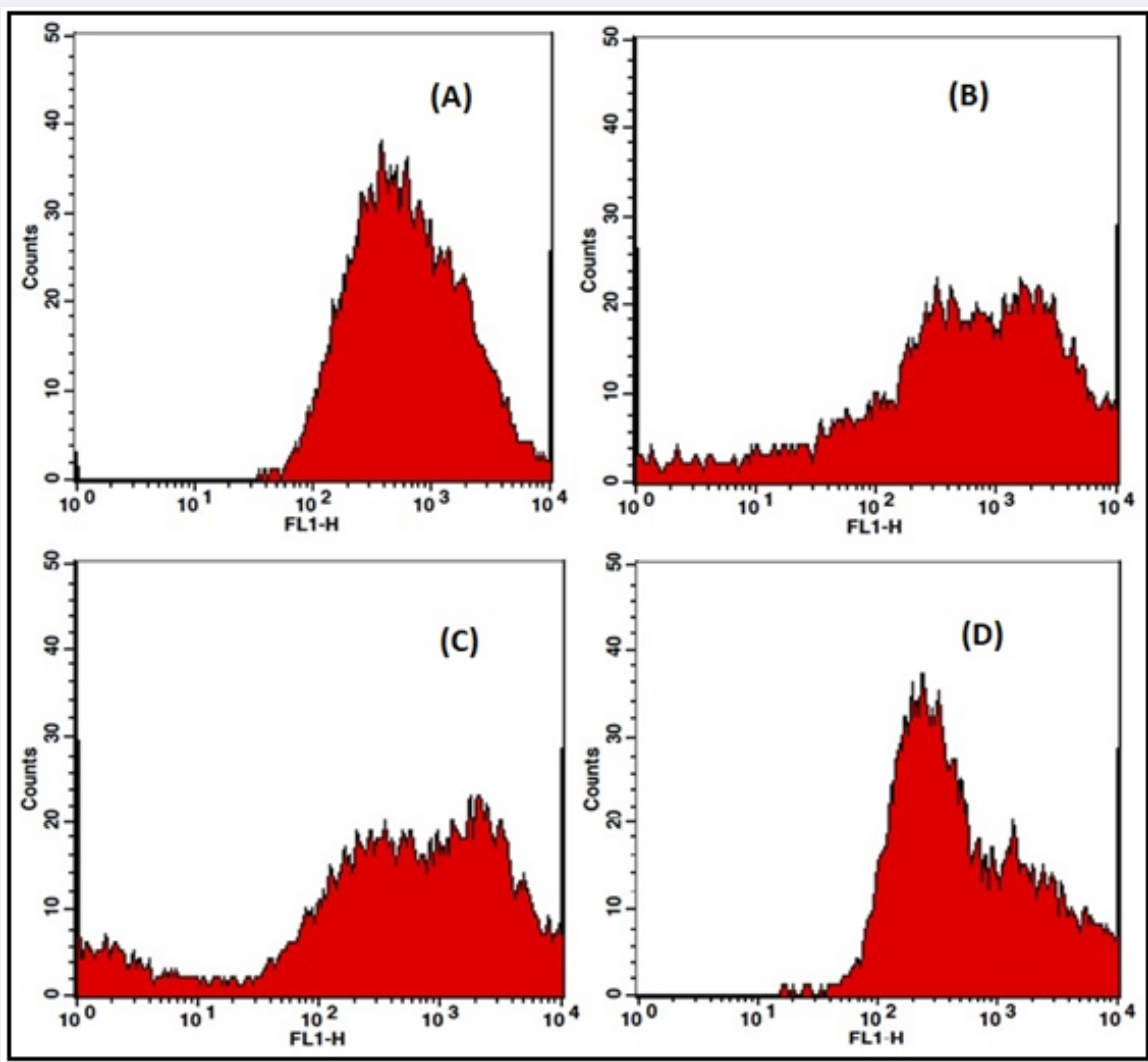

Figure 17: 2 D plots of Flow Cytometry of Isoniazid from the patches (A) at 3 hours, (B) at 6 hours, (C) at 12 hours (D) at 24 hours. 


\section{Comparisons of cellular uptake for different nanoparticle loaded patches at different time points}

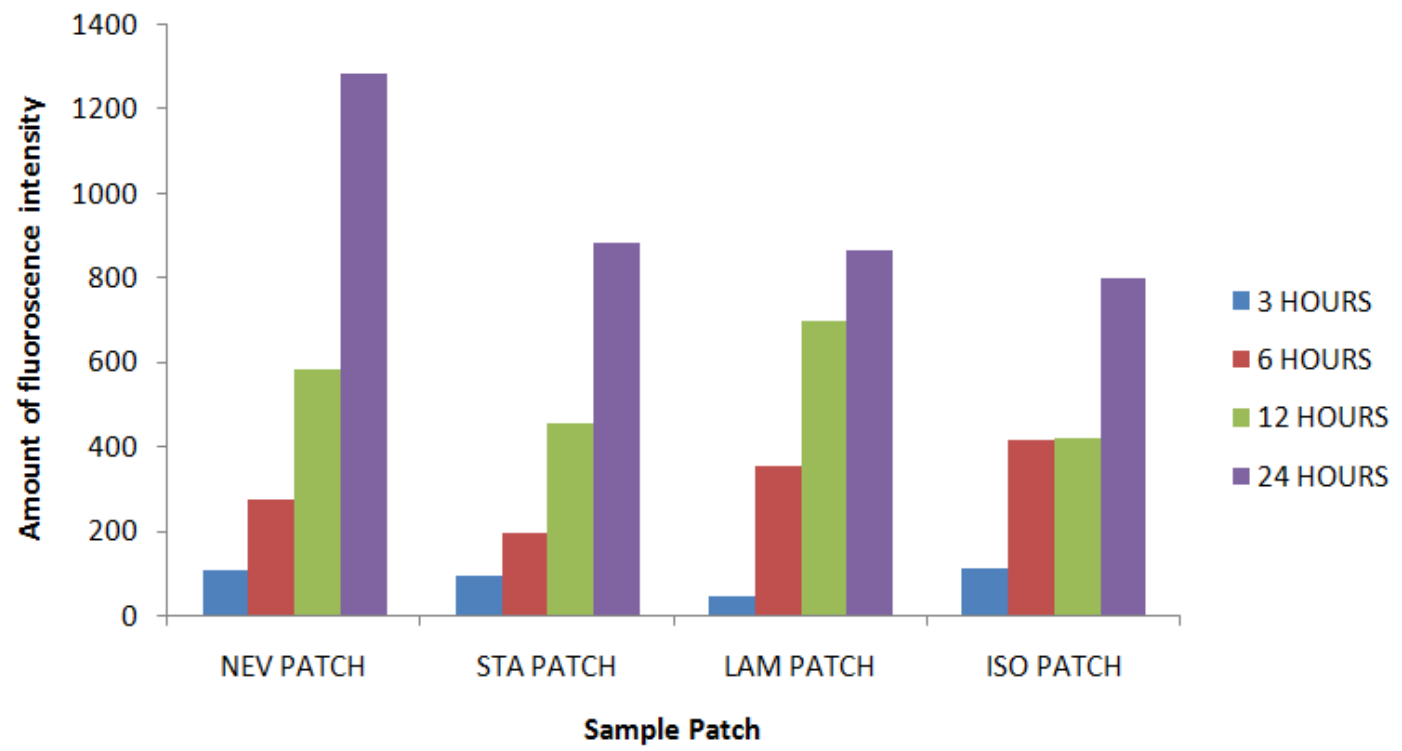

Figure 18: Comparison of cellular uptake for different nanoparticles loaded patches at different time points.

Table 4: Quantitative estimation of drug up taken by the cells.

\begin{tabular}{|c|c|c|c|c|c|}
\hline \multirow{2}{*}{ S. No. } & \multirow{2}{*}{ Formulation } & \multicolumn{4}{|c|}{ Peak Values of flow cytometry } \\
\cline { 3 - 6 } & & At 3 hour & At 6 hour & At 12 hour & At 24 hour \\
\hline 1 & NEV-patch & 106 & 271 & 482 & 879 \\
\hline 2 & STA-patch & 94 & 193 & 696 & 864 \\
\hline 3 & LAM-patch & 46 & 413 & 419 & 798 \\
\hline
\end{tabular}

\section{Acknowledgement}

The authors gratefully acknowledge financial support in the form of research grant RGU: Res: Wing: 2014-15 from Rajiv Gandhi University of Health Sciences, Bangalore- 560040. The authors also acknowledge Skanda Labs Pvt. Ltd, Bangalore to provide their best assistance in carrying out the cell line uptake study at their facility. The authors would like to thank the Principal and the management of Al-Ameen College of Pharmacy for their support to carry out this research work.

\section{References}

1. Maartens G, Celum C, Lewin SR (2014) HIV infection: epidemiology, pathogenesis, treatment, and prevention. The Lancet 384(9939): 258271.

2. (2018) The AIDS epidemic continues to take a staggering toll, but progress is possible. UNICEF, India.
3. (2018) HIV (Human Immunodeficiency Virus). United States Food and Drug Administration, Maryland.

4. Khakshour A, Moghadam HT, Kiani MA, Saeidi M, Zarif B (2014) Key facts about Epidemiology of HIV/AIDS in Children Worldwide. International Journal of Paediatrics 2(2.2): 145-152.

5. Nath A (2017) Pediatric HIV in India: Current Scenario and the way forward. Indian Journal of Public Health 61(2): 124-130.

6. Brechtl JR, Breitbart W, Galietta M, Krivo S, Rosenfeld B (2001) The use of highly active antiretroviral therapy (HAART) in patients with advanced HIV infection: impact on medical, palliative care and quality of life outcomes. Journal of pain Symptom Manage 21(1): 41-51.

7. (2017) Anti-retroviral therapy. World Health Organization.

8. Jaen A, Buira E, Giménez A, Pumarola T, Puig T, et al. (2015) Impact of Fixed-Dose Combinations of Antiretrovirals on Prevalence Trends of HIV Resistance: A7 Year Follow-Up Study. J AIDS Clin Res 6(1): 416.

9. Garcia MV, Mukeba Tshialala D, Moutschen M (2009) A fixed dose antiHIV combination for the poor? Triomune. Rev Med Liege 64(1): 32-36. 
10. Dey S, Pramanik S, Malgope A (2011) Formulation and Optimization of sustained release Stavudine microspheres using response surface methodology. ISRN Pharmaceutics.

11. Arts EJ, Hazuda DJ (2012) HIV-1 Antiretroviral Drug Therapy, Cold Spring Harbor Perspectives in Medicine 2(4).

12. Lohani A, Verma A, Joshi H, Yadav N, Karki N (2014) Review Article Nanotechnology Based Cosmeceuticals. ISRN Dermatology.

13. Sulis G, Roggi A, Matteelli A, Raviglione MC (2014) Tuberculosis: Epidemiology and Control. Mediterranean Journal of Hematology and Infectious Diseases 6(1): e2014070.

14. Madhi SA, Nachman S, Violari A, Kim S, Cotton MF, et al. (2011) Primary Isoniazid Prophylaxis against Tuberculosis in HIV-Exposed Children. New England Journal of Medicine 365: 21-31.

15. Chan ED, Iseman MD (2002) Current medical treatment for tuberculosis. British Medical Journal 325(7375): 1282-1286.

16. Koyi PK, Khan AB (2013) Buccal Patches: A Review. Int J Pharm Sci Res 4(1): 83-89.

17. Adhikari SNR, Nayak BS, Nayak AK, Mohanty B (2010) Formulation and Evaluation of Buccal Patches for Delivery of Atenolol. AAPS Pharm Sci Tech 11(3): 1038-1044.

18. Ikram Md, Gilhotra N, Gilhotra RM (2015) Formulation and optimization of mucoadhesive buccal patches of losartan potassium by using response surface methodology. Advanced Biomedical Research 4: 239 .

19. Semalty M, Semalty A, Kumar G (2008) Formulation and Characterization of Mucoadhesive buccal films of Glipizide. Indian Journal of Pharmaceutical Sciences 70(1): 43-48.

20. Semalty A, Semalty M, Nautiyal U (2010) Formulation and Evaluation of Mucoadhesive Buccal Films of Enalapril Maleate. Indian Journal of Pharmaceutical Sciences 72(5): 571-575.
21. Lodhi M, Dubey A, Narayan R, Prabhu P, Priya S (2013) Formulation and Evaluation of buccal film of Ivabradine hydrochloride for the treatment of stable angina pectoris. International Journal of Pharmaceutical Investigation 3(1): 47-53.

22. Alagusundaram M, Chengaiah B, Ramkanth S, Parameswari SA, Chetty CMS, et al. (2009) Formulation and Evaluation of Mucoadhesive buccal films of Ranitidine. International Journal of PharmTech Research 1(3): 557-563.

23. Trastullo R, Abruzzo A, Saladini B, Gallucci MC, Cerchiara T, et al (2016) Design and Evaluation of buccal films as paediatric dosage form for transmucosal delivery of ondansetron. European Journal of Pharmaceutics and Bio pharmaceutics 105: 115-121.

24. El Maghraby GM, Abdelzaher MM (2015) Formulation and evaluation of simvastatin buccal film. Journal of Applied Pharmaceutical Science 5(4): 70-77.

25. Saxena A, Tewari G, Saraf AS (2011) Formulation and evaluation of mucoadhesive buccal patch of acyclovir utilizing inclusion phenomenon. Brazilian Journal of Pharmaceutical Sciences 47 (4): 887-897.

26. Pednekar T, Pillai SS, Shabaraya AR, Azharuddin M (2012) Design and Evaluation of Buccal Films of an Antihypertensive Drug. Design and Evaluation of Buccal Films of an Antihypertensive drug. American Journal of PharmTech Research 2(5): 710-722.

27. De PK, Mallick S, Mukherjee B, Sengupta S, Pattnaik S, et al. (2011) Optimization of In-vitro permeation pattern of kerotolac tromethamine transdermal patches. Iranian Journal of Pharmaceutical Research 10(2): 193-201.

28. Alai M, Lin WJ (2014) Novel lansoprazole-loaded nanoparticles for the treatment of gastric acid secretion-related ulcers: in vitro and in vivo pharmacokinetic pharmacodynamic evaluation. The AAPS journal 16(3): 361-372.

\begin{tabular}{l} 
Your next submission with Juniper Publishers \\
will reach you the below assets \\
- Quality Editorial service \\
- Swift Peer Review \\
- Reprints availability \\
- E-prints Service \\
- Manuscript Podcast for convenient understanding \\
- Global attainment for your research \\
- Manuscript accessibility in different formats \\
( Pdf, E-pub, Full Text, Audio) \\
- Unceasing customer service \\
Track the below URL for one-step submission \\
https://juniperpublishers.com/online-submission.php \\
\hline
\end{tabular}

